\title{
WHO GETS ON THE NEWS? \\ The relation between media biases and different actors in news reporting on complex policy processes
}

\section{Public Management Review, published online: 02 Sep 2013}

Iris Korthagen (korthagen@fsw.eur.nl) works at the Department of Public Administration at Erasmus University Rotterdam

Department of Public Administration

Erasmus University Rotterdam

P.O. Box 1738

3000 DR Rotterdam

The Netherlands

\section{Acknowledgements}

This article is written within the research project "complex decision-making in a drama democracy", financed by NWO, project number 3010042005. An earlier versions of this article is presented at the PSA Media and Politics Specialist Group Annual Conference. Special thanks to Erik Hans Klijn and Steven van de Walle for their valuable comments on earlier versions of this article. Moreover, the author likes to thank the ten students, for their valuable coding work in their research project in bachelor 3 . 


\title{
WHO GETS ON THE NEWS? The relation between media biases and different actors in news reporting on complex policy processes
}

\begin{abstract}
Having a voice in media is important to gain power and legitimacy in policy processes. However, media are biased in transmitting information. Using a quantitative content analysis of ten years' news reporting around water management policies in the Netherlands, we study how much media attention different groups of actors receive and how media biases relate to this attention. Executive politicians get on the news because of their authoritative position; less authoritative actors getting on the news is more related to information biases. Information biases can thus function as a form of checks and balances in news reporting on policy processes.
\end{abstract}

Keywords: Media, media logic, governance network, official dominance, information biases

\section{INTRODUCTION}

Much decision making takes place in governance networks, with a variety of official and unofficial actors involved in the policymaking processes (Koppenjan and Klijn, 2004; Klijn, 2008). In these governance networks, there is much uncertainty and no consensus with regard to the formulation of policy problems and solutions (Hisschemöller and Hoppe, 1995; Koppenjan and Klijn, 2004; Rittel and Webber, 1973). Actors involved in the policy process have dissimilar interests; as a result, there are many perspectives on 
both problems and solutions. Because these policy issues are contested, they will often be publicly discussed in the media (Voltmer and Koch-Baumgarten, 2010). In public administration, much attention is paid to complex policy processes, but scarcely any to the construction of those processes in news reports.

News reporting is important for all actors in a governance network. Having a voice in the media is an important political strategy to gain power and legitimacy in policy processes (Tresch, 2009). Groups of actors without authoritative power resources in the decision-making process need media to gain power (Cobb and Elder, 1983; Baumgartner and Jones, 2009; Sireau and Davis, 2007; Voltmer and Koch-Baumgarten, 2010; Kunelius and Reunanen, 2011). News coverage of a citizen group's statements, for instance, may change the targets and efforts of decision makers who use the news as a surrogate for public opinion (Entman, 2007). But officials also attempt to reinforce their own position by publicity, especially if they fail to realize their goals by the traditional means of participation and negotiation in the policy process (Tresch, 2009; SpörerWagner and Marcinkowski, 2010). Moreover, governing officials need the media to legitimate their policy plans and decisions (Hurrelman et al., 2009). Media coverage of policy processes in governance networks is therefore an important study object, deserving more attention in public administration research. This is particularly true in times of increasing mediatization within present-day Western democracies, in which the media and their logic have become more and more important (Mazzoleni and Schulz, 1999; Hjarvard, 2008; Hajer, 2009; Strömbäck and Esser, 2009; Reunanen et al., 2010).

Media logic refers to 'the process through which the media present and transmit information' (Altheide and Snow, 1979: 10). The media are not neutral transmitters of 
information. The process of news-making depends to a great extent on the news value that journalists ascribe to an event or viewpoint, and organizational pressures on journalists such as deadlines and economic goals. This leads to certain patterns in news reporting. Research in the field of (political) communication has identified two media bias trends: firstly, the trend of official dominance, indicating that journalists rely heavily on official sources in their news reporting; secondly, information biases, whereby news is increasingly negative (towards authorities), as well as dramatized, fragmentized and personalized.

These aspects of media logic have an important influence on who will get access to the public and how those actors' public images are formed (Altheide and Snow, 1979; Mazzoleni and Schulz, 1999). To date, studies conducted on official dominance or on information biases mostly concern general trends in (political) news reports (Sigal, 1973; Gans, 1979; Shehata, 2010; Patterson, 2000) or election coverage (Tresch, 2009'; Hopmann et al., 2011; Brants and Neijens, 1998; Brants and van Praag, 2006; Kleinnijenhuis $e t$ al., 2006). ${ }^{2}$ In a more multifaceted setting of a complex policy process - where it is not all about the politicians, as in election periods, but various public, semipublic and private actors are involved - the results might be different.

In this article, we analyse ten years of news reporting on five comparable water management projects, representing cases of complex policy processes (van Burren et al., 2010). We are interested in how much media attention different groups of actors receive and how the identified media biases relate to this media attention.

\footnotetext{
${ }^{1}$ More precisely Tresch (2009) studies news reports in the context of two referenda: on a set of bilateral agreements with the EU and on a popular initiative "Yes to Europe."

${ }^{2}$ An important exception is Baumgartner and Jones, 2009. They discuss the biases of negativity and conflict in their book on policy processes.
} 
We distinguish four groups of actors in our analysis. Firstly, there are governing officials: executive politicians such as ministers, provincial governors and aldermen. Secondly, there are non-governing officials, who are members of the lower house and from provincial and municipal councils. The third category, administrative officials, mostly represents the project organization. Lastly, the unofficial actors' category mainly encompasses various citizen groups. These four groups of actors have different interests in gaining media attention, and they generally represent different perspectives on policies. Governing officials mainly strive to ensure that their policies attract positive attention, whereas unofficial actors and non-governing officials rather try to open up the policy process by publicly questioning these policies.

We start this article with a theoretical elaboration, mainly by zooming in on official dominance and information biases in news reports. In the second section, we discuss our data and methods. Thirdly, we present the results. Lastly, we discuss our conclusions.

\section{COMPLEX POLICY PROCESSES IN THE CONTEXT OF MEDIATIZATION}

Many policy problems can be characterized as 'wicked' (Rittel and Webber, 1973; Mason and Mitroff, 1981; Koppenjan and Klijn, 2004). Wicked problems are ill-defined, and solutions to such problems rely on extensive negotiations between different actors. Planning problems are a good example of wicked problems, with implications for policy making. There is a broader participation of affected parties, directly and indirectly, in the policy process (Mason and Mitroff, 1981). All kinds of actors are part of the decisionmaking process, such as representatives of municipalities, provinces, private enterprises 
and interest groups. Horizontal relations between these actors replace hierarchical relations, resulting in governance networks (Hajer and Wagenaar, 2003; Koppenjan and Klijn, 2004). Interdependencies between actors are predominant in these governance networks. No single actor has the final coercive power to fulfil his/her policy plans, because of these interdependencies (Sorensen and Torfing, 2005).

In policy games, the actors with divergent interests, goals and perceptions pull and push to bring about problem formulations and policy measures (Koppenjan, 2007). Because little agreement exists between them with regard to the problem or the solution, negotiations among the actors will seldom lead to unanimous consensus. As Sorensen and Torfing (2005: 203) argue: 'deliberation takes place in a context of intense power struggles and the presence of disagreements, conflicts and social antagonism that means that political decisions will often be made on the basis of a "rough consensus" where grievances are unavoidable, but tolerable.'

Although no actor has the final coercive power in policy games, power differences do exists, due to differences in power resources such as knowledge, money or political position (Hajer and Wagenaar, 2003; Koppenjan and Klijn, 2004; Koppenjan, 2007). The ability to anticipate and mobilize media attention is another power resource in policy games (Cobb and Elder, 1983; Baumgartner and Jones, 2009; Hajer, 2009; Tresch, 2009; Spörer-Wagner and Marcinkowski, 2010; Kunelius and Reunanen, 2011). As discussed in the introduction, with publicity for their viewpoint, actors can strengthen their position in negotiations in policy processes. This power resource has become increasingly important in the age of mediatization (Hajer, 2009). 
Competition over media access is, however, guided and restricted by media logic: the process of news-making led by the media's aims, production routines and selection criteria (Tresch, 2009). This has led to certain trends in news reporting: official dominance and information biases in news reports. We further discuss these trends in the next two sections.

\section{Official dominance: News is about the powerful}

The more powerful position an actor holds, the more media attention he/she automatically receives. This is referred to as the incumbency bonus (Hopmann et al., 2011) or as official dominance (Shehata, 2010). Studies dating back as far as the 1970s still frequently cited - had already concluded that the majority of the news reports are written about officials (Gans, 1979; Sigal, 1973). More recent studies also confirm that officials dominate the news (Tresch, 2009; Shehata, 2010).

Explanations for official dominance in the news mainly include professional journalistic norms and efficiency aims within media businesses (Bennett, 1996; Shoemaker and Reese, 1996; Cook, 2005; Bennett, 2009). Reliance on officials is partly due to the news value of officials' behaviours and viewpoints. The newsworthiness of actors' perspectives or actions is at least partially determined by the power and influence

of those actors (Bennett, 1996; Shoemaker and Reese, 1996; Shehata, 2010; Hopmann et al., 2011). Actions of the powerful are newsworthy because what the powerful do affects the general public. Tresch (2009: 71) therefore argues that 'formal power in the policymaking process therefore easily translates into discursive power in the media, which can 
further strengthen the political power of an actor and ultimately lead to a selfperpetuating cycle of political influence and media coverage'. .'

Moreover, reliance on governing officials is rooted in journalistic norms of objectivity and in the political obligation to provide some degree of democratic accountability (Bennett, 1996). Officials are seen as providing 'factual,' authoritative and legitimate information.

In addition, governing officials are mostly very efficient news sources. Authorities increasingly invest in 'selling' their policies and managing their public relations (Cook, 2005; Eshuis and Klijn, 2012). Public relations practitioners make governmental information easily accessible to journalists (Gandy, 1982; Lieber and Golan, 2011). In times of intensifying pressures on journalists due to the heavy competition in the news market, journalist are increasingly dependent on these ‘information subsidies’ supplied by official sources (Gandy, 1982). Consequently, many news reports arise in close collaboration between reporters and governing officials, and their media advisers.

Whereas officials are newsworthy because of their influential position, others, who lack habitual access to the media, have to rely on disruptive events (Shehata, 2010) or other news values (Parkinson, 2006) in order to become newsworthy. Hence, one way for other actors to get publicity for their viewpoint is to organize events such as protests (Shoemaker and Reese, 1996; Terkildsen et al., 1998). This fulfils their need to get media coverage, but it also fulfils the media's need for news (Shoemaker and Reese, 1996). Besides this organization of (pseudo) events and drama, using sound-bites and personalizing a story are other ways to attract media attention (Parkinson, 2006). The 
information biases in the news (Patterson, 2000; Bennett, 2009) can therefore be seen as a trend in news reporting that facilitates the relations between journalists and unofficial actors or non-governing officials.

\section{The other side: Information biases}

Wicked policy processes are either avoided by journalists or drastically reshaped to fit journalistic norms (Davis, 2007). Bennett (2009) describes four trends in current news reporting that, in his opinion, simplify complex governmental issues. He sees trends of personalization, dramatization, fragmentization and an authority-disorder bias, which he calls information biases. In addition, Patterson (2000) sees a bias towards negativity in the news. These five trends in the framing of news can also be found in other studies on media content.

The personalization bias refers to the framing of stories in terms of human interest. It brings a human face or emotional angle to the presentation of an issue (Bennett, 2009; Patterson, 2000; Semetko and Valkenburg, 2000).

The dramatization bias concerns an emphasis on crisis and conflict in stories rather than on continuity and harmony (Patterson, 2000; Bennett, 2009). Journalists tend to describe the situation at hand in terms of conflicts, with winners and losers (Brants and Neijens, 1998; Brants and van Praag, 2006; Hopmann et al., 2011; Semetko and Valkenburg, 2000; Strömbäck and Shehata, 2007).

The isolation of stories from one another and from their larger context is called the fragmentization bias (Bennett, 2009; Iyengar and McGrady, 2007; Patterson, 2000; Strömbäck and Shehata, 2007; Semetko and Valkenburg, 2000). In this 'episodic' 
framing, journalists describe issues in terms of specific events; they do not place them in their more general context (Iyengar and McGrady, 2007).

The news is furthermore preoccupied with order, as journalists question whether authorities are capable of establishing or restoring the order (Bennett, 2009; Semetko and Valkenburg, 2000). At the same time, the media's attitude towards authorities is shifting from a more favourable stance towards an attitude where the media are more suspicious of authorities (Bennett, 2009; Kleinnijenhuis et al., 2006). This bias is known as the authority-disorder bias.

Lastly, the tendency of the news to be more negative in general (Patterson, 2000) reflects a negativity bias.

These five information biases can be seen in two different ways. While factors of personification, negativity and a focus on drama and conflict are part of the classical news factor theory of Galtung and Ruge (1965), nowadays these news factors give rise to much criticism regarding the quality of news; they are seen as information biases. Bennett (2009: 40) introduces the information biases in his book as follows: 'In particular, four characteristics of news stand out that public information in the United States does not always advance the cause of democracy.' Many other prominent scholars also accuse journalists of making political news more spectacular and entertaining, while providing less substantive information (e.g. Patterson, 2000; Delli Carpini and Williams, 2001; Davis, 2007; Bennett, 2009). This is explained in the literature by competition for the attention of the news consumer and - again - efficiency aims (Bennett, 2009; Davis, 2007; Delli Carpini and Williams, 2001). 
However, the information biases can be approached more positively as well. Shehata (2010: 127) claims that 'framing politics as a game rather than focusing on issues, policy positions and ideologies is ... a way for journalists to distance themselves from politicians and to impose their own "professional" lens on politics.' Reporting on aspects of politics other than those promoted by politicians thus demonstrates journalistic independence. Schudson (2009) even argues that an unlovable press is essential for the functioning of democracy. The very characteristics of media logics that other scholars criticize - the pre-occupation with events, with conflicts, the cynism - give journalists the opportunity to subvert established power in the deliberative process, Schudson (2009) claims. Conflicts and news dramas therefore do not only 'downplay information on complex policy information and the workings of government institutions' as Bennett (2009: 41) states. Zooming in on citizens potentially affected by the policies shows a different side of the policy story. In contrast to the official dominance thesis, information biases might indicate that a news story is more independent of governing officials. More conflict, negativity and human interest in a news story can thus also be a form of checks and balances.

\section{Hypotheses}

On the basis of the literature discussed, we can develop some - although merely explorative - hypotheses on the media coverage of the complex policy processes under study.

The official dominance thesis leads to the following two hypotheses:

H1: Officials will be more often the key subjects in a news report than unofficial actors. 
$H 2$ : Governing officials will be more often the key subjects in a news report than nongoverning officials.

The information biases thesis leads to another three hypotheses:

H3: The mean ranks on the information biases in news about governing officials and administrative officials differ significantly from the mean ranks of non-governing officials and unofficial actors.

H4: The personalization bias, dramatization bias, fragmentization bias, authority-disorder bias and negativity bias are more often present in news about unofficial actors than in news about governing officials.

H5: The personalization bias, dramatization bias, fragmentization bias, authority-disorder bias and negativity bias are more often present in news about non-governing officials than in news about governing officials.

The data and methods we used to test these hypotheses are described in the following section on methodology.

\section{METHODOLOGY}

\section{Data: Five water management cases}

We studied news reports on five complex water management cases in the Netherlands over a ten-year period. Initiative for these projects is taken by the national government or by provinces. The cases can be seen as representative regional water projects conducted in the Netherlands (van Buuren et al., 2010; Edelenbos et al., 2013). Information about the main issues, the policy initiator and the current state of the different cases can be found in Table 1. 
Table 1: Information about the five water management cases

\begin{tabular}{|c|c|c|c|c|c|}
\hline & IJsseldelta-Zuid & Lent & Noordwaard & Wieringerrandmeer & Zuidplaspolder \\
\hline $\begin{array}{l}\text { Time } \\
\text { period }\end{array}$ & 2000-to date & 1993-to date & 2000-to date & $1998-2009$ & 2001-to date \\
\hline Initiator & Province & $\begin{array}{l}\text { National } \\
\text { government }\end{array}$ & $\begin{array}{l}\text { National } \\
\text { government }\end{array}$ & Province & Province \\
\hline $\begin{array}{l}\text { Main } \\
\text { issues }\end{array}$ & $\begin{array}{l}\text { Creating a bypass for } \\
\text { water storage, with } \\
\text { implications for a } \\
\text { railway and a motorway } \\
\text { in that area, combined } \\
\text { with the building of } \\
\text { new dwellings and } \\
\text { recreational area. }\end{array}$ & $\begin{array}{l}\text { Shifting the dikes } \\
\text { for water storage, } \\
\text { combined with the } \\
\text { building of new } \\
\text { dwellings and a } \\
\text { new bridge. }\end{array}$ & $\begin{array}{l}\text { Shifting the } \\
\text { dikes for water } \\
\text { storage and } \\
\text { stimulating } \\
\text { recreational } \\
\text { activities in the } \\
\text { area. }\end{array}$ & $\begin{array}{l}\text { Creating a large } \\
\text { lake and building } \\
\text { new dwellings } \\
\text { (enhancing tourism } \\
\text { and creating } \\
\text { economic } \\
\text { incentives for the } \\
\text { area). }\end{array}$ & $\begin{array}{l}\text { Redeveloping a } \\
\text { polder (land } \\
\text { reclaimed from the } \\
\text { sea) and creating } \\
\text { space for new } \\
\text { dwellings, water } \\
\text { storage and space } \\
\text { for glass houses. }\end{array}$ \\
\hline $\begin{array}{l}\text { Current } \\
\text { stage }\end{array}$ & $\begin{array}{l}\text { Delayed } \\
\text { implementation }\end{array}$ & Implementation & Implementation & Cancelled & $\begin{array}{l}\text { Delayed and } \\
\text { downsized } \\
\text { implementation }\end{array}$ \\
\hline
\end{tabular}

Note: Based on the case studies of van Buuren et al. (2010) and Edelenbos et al. (2013)

Water management is in all cases combined with other planning activities such as housing, the development of recreational areas or infrastructure. This combination of tasks increases the number of public and private actors involved in the decision-making process. Van Buuren et al. (2010) also note a more general trend of an increasing involvement of citizen groups, not only in water projects, but also in other public decision-making processes.

Regarding the water policy measures executive and non-executive politicians from local, regional and national government; water boards, bureaucrats from ministries, provinces and municipalities; and representatives from citizen groups, private investors and research institutes are involved. Most actors have different interests and different perspectives on the project. Besides this, knowledge on the issues is limited and contested. For instance, conflicting opinions exist on the necessity for extra water storage in the areas and the amount of water that will have to be managed in the future. Van Buuren et al. (2010) therefore characterize these water management issues as wicked. 
News media facilitate the public debate on these projects. Moreover, media attention for your stance can be seen as a power resource in decision making processes. It is thus important to see which actors are covered in news reports on these wicked issues.

\section{Data collection}

We obtained our data from newspapers and the television. We included the regional media newspaper(s) of that region and five national newspapers with different political orientations $^{3}$. The search in the Lexis Nexis Academic NL database ${ }^{4}$ concentrated on the period between 1 January 2000 and 1 January 2010 . We used the name of the case ${ }^{5}$ as the search term.

Reports were deemed to belong to the universe only when more than one paragraph $^{6}$ was written on the relevant water management project. If the universe of regional news reports for one specific case comprised more than 150 items, we took a random sample per project. ${ }^{7}$ The number of national news reports exceeded that threshold for sampling in none of the cases. We analysed television items about the water management projects using the Netherlands Institute for Sound and Vision website (http://portal.beeldengeluid.nl/) and regional broadcasters' websites. We included all television items in our analysis, since they were few in number.

\footnotetext{
${ }^{3}$ Algemeen Dagblad, De Telegraaf, de Volkskrant, NRC Handelsblad and Trouw

${ }^{4}$ Although Lexis Nexis is the most comprehensive newspaper database in the Netherlands - containing all national, regional and local newspapers in the country - the coverage of some newspapers with a merely regional character did not start until after 2000. This may have led to some biases in the sample.

${ }^{5}$ IJsseldelta-Zuid, dijkteruglegging Lent, Noordwaard, Wieringerrandmeer and Zuidplaspolder.

${ }^{6}$ Or when the report itself was just one paragraph and it concerned the water management project.

${ }^{7}$ Between 150 and 300 reports: the sample consists of the first of every two reports (for Noordwaard and Wieringerrandmeer); between 300 and 450 reports: the sample consists of the first of every three reports (for Zuidplaspolder).
} 
The total universe consisted of 1,011 news reports; after sampling the regional newspaper reports, we had a total sample of 566 news reports. More than 10 percent (13.6 per cent) of the reports come from national news media, and the rest come from regional media (86.4 per cent). Newspapers reported significantly more often about the projects than television, with, respectively, 536 (94.7 per cent) and 30 items $^{8}$ (5.3 per cent).

\section{Method: Quantitative content analysis}

The unit of analysis was a news report. We used Patterson's (2000) established coding scheme to typify each report regarding the information biases. We also used his instructions with regard to conceptualization as can be seen in Appendix 1. This scheme is more elaborate than those used in other studies, which have tended to focus on just a selection of information biases (see for instance Brants and Neijens, 1998; Brants and van Praag, 2006; Kleinnijenhuis et al., 2006; Semetko and Valkenburg, 2000; Strömbäck and Shehata, 2007). Moreover, Patterson's codes (2000) can be easily translated into the information biases described by Bennett (2009) (because Bennett builds on Patterson's research). In addition, we created a coding variable for the actor who was the key subject of the news report. The categories of this variable (23 actors in total) were based on earlier case study research on these projects (van Buuren et al., 2010). We recoded this item into four categories for the purpose of this study, into governing officials, nongoverning officials, administrative officials and unofficial actors (see Table 2).

\footnotetext{
${ }^{8}$ However, we must remark that it is only quite recently that regional television programmes can be found on the Internet. The earliest item from regional television is from March 2006, and the date regional broadcasters started their broadcasting on the Internet may even differ per outlet. This may lead to small biases in the analysis.
} 
Five teams of trained coders executed the coding of the news reports, with the help of an extensive coding instruction. We executed two tests of reliability, using conformity tests. Conformity of 0.90 or higher leads to a reliability score above 0.80 on all types of reliability measures (Wester and van Selm, 2006). First, intra-observer reliability (Krippendorf, 2004) was tested; the stability of the coders was on average 0.94 . Secondly, inter-coder reliability (Krippendorf, 2004) was tested, resulting in an average of 0.90 . Hence, we conclude that the data set can be seen as reliable: there is not much 'noise' hampering accurate statistical analysis of these data.

To analyse the data, we used SPSS version 20.0. Both the Kolmogorov-Smirnov statistic and the Shapiro-Wilk statistic were highly significant for the data among the four different groups of actors; this means that the different distributions are all non-normal. We therefore used non-parametric statistical methods. Instead of assuming normal distributions, these methods calculate the test statistics with ranked data (Conover and Iman, 1981). The lowest score in the data - including all groups - is given a rank of 1; the next lowest score is given a rank of 2 , and so on . In case of similar scores, this is referred to as ties, average ranks are assigned. The tests are carried out on the ranks rather than the actual data (Conover and Iman, 1981; Field, 2009).

We have examined significant differences between the four groups in our analysis with the Kruskal-Wallis test, which can be seen as a non-parametric ANOVA. The Kruskal-Wallis test calculates whether the mean ranks for the groups differ significantly. With post-hoc tests provided by SPSS 20.0 we calculate pairwise comparisons; we test for significant differences between the mean ranks of two groups. These post-hoc tests 
correct for type I errors by the Dunn-Bonferroni test; they calculate an adjusted significance value.

\section{MEDIA COVERAGE OF THE WATER MANAGEMENT PROJECTS}

\section{The official dominance thesis}

We firstly examine whether officials indeed dominated the news reporting on the water management projects. Table 2 reports the percentages of how relatively often the different actors were the most important actor in a news report. Per news report, only one of the actors could be chosen as key actor.

Table 2: Media coverage of actors: percentages of actors as key subjects in a news report

\begin{tabular}{|c|c|c|c|}
\hline \multirow{10}{*}{ Officials (56.5\%) } & \multirow{7}{*}{$\begin{array}{c}\text { Governing officials } \\
(31.6 \%)\end{array}$} & (Prime) minister & $6.9 \%$ \\
\hline & & The state & $0.4 \%$ \\
\hline & & Provincial governor & $7.2 \%$ \\
\hline & & The province & $1.9 \%$ \\
\hline & & Mayor & $1.8 \%$ \\
\hline & & Aldermen & $5.1 \%$ \\
\hline & & The municipality & $6.4 \%$ \\
\hline & \multirow{4}{*}{$\begin{array}{c}\text { Non-governing officials } \\
(13.8 \%)\end{array}$} & Water board & $1.9 \%$ \\
\hline & & Member of the lower house & $4.4 \%$ \\
\hline & & Member of the provincial council & $2.7 \%$ \\
\hline \multirow{10}{*}{$\begin{array}{l}\text { Unofficial actors } \\
\quad(43.5 \%)\end{array}$} & & Member of the municipal council & $6.7 \%$ \\
\hline & \multirow{4}{*}{$\begin{array}{l}\text { Administrative officials } \\
(11.1 \%)\end{array}$} & Administrative officials & $3.0 \%$ \\
\hline & & Metropolitan region & $0.4 \%$ \\
\hline & & Project organization & $7.8 \%$ \\
\hline & & Inhabitants (association) & $17.1 \%$ \\
\hline & \multirow{5}{*}{$\begin{array}{l}\text { Unofficial actors } \\
\quad(43.5 \%)\end{array}$} & Farmers & $6.7 \%$ \\
\hline & & Environmental organizations & $7.1 \%$ \\
\hline & & Private investors & $3.2 \%$ \\
\hline & & Research institute & $3.9 \%$ \\
\hline & & Other & $5.5 \%$ \\
\hline
\end{tabular}

In Table 2, we see that officials are the main subject of the story in 56.5 per cent of the news reports, against 43.5 per cent of the news reports on unofficial actors. So, officials, including governing officials, non-governing officials and administrative officials, are 
somewhat more often the key subject of a news report than unofficial actors. It seems that the officials indeed to some extent benefit from the newsworthiness value they automatically possess and the information subsidies that they provide.

However, the contrast between the groups of officials and unofficial actors is not as strong as we expected, following the theoretical notions on official dominance. Particularly, in comparing attention on governing officials (key actors in 31.6 per cent of the news reports) with attention on unofficial actors (key actors in 43.5 per cent of the news reports), the conclusion must be nuanced. Governing officials do not really dominate the news among the complex water management projects under study. Nevertheless, the majority of the news reports do have an official as their key subject. Although with reservations, we can confirm the expectation stated in H1.

Within the category of officials, we make a distinction between governing officials, non-governing officials and administrative officials. We see that governing officials are the main subject of the story in 31.6 per cent of the news reports, against 13.8 per cent of the news reports mainly concerning non-governing actors. Governing officials' actions have generally more consequences for citizens and have therefore more news value than actions of non-governing officials. Moreover, governing officials generally have more resources to invest in their communication strategies than nongoverning officials. We indeed see that governing officials are more often the most important actors in a news report than non-governing officials, thereby confirming hypothesis $\mathrm{H} 2$. 


\section{The information biases thesis}

The relatively large share of news reports in which unofficial actors are the key subject might be related to the other trend in news reports: information biases. As discussed in the theoretical section, we expect unofficial actors and non-governing officials to get more publicity by adapting to the media's needs. By providing dramatic events, conflict, critical accounts and human interest, these actors acquire more news value as well.

In Table 3, we report the frequencies of information biases. Frequencies in bold show the percentages of the news reports in which the relevant information bias is clearly present. ${ }^{9}$

Table 3: The frequencies of the biases categories

\begin{tabular}{lll}
\hline & Categories & Percentage \\
\hline Fragmentization & Thematic & 22.8 \\
& Episodic & $\mathbf{7 7 . 2}$ \\
\cline { 2 - 3 } Personalization & No (or merely incidental) human interest & 54.6 \\
& Slight human interest content & 21.6 \\
& Moderate human interest content & $\mathbf{1 2 . 7}$ \\
& High human interest content & $\mathbf{1 1 . 1}$ \\
\cline { 2 - 3 } Dramatization & No conflict framing & 36.0 \\
& Some conflict framing & 31.3 \\
Authority-disorder & Substantial level of conflict framing & $\mathbf{3 2 . 7}$ \\
\cline { 2 - 3 } bias & No authority-disorder bias & 50.4 \\
& Authority-disorder bias & $\mathbf{4 9 . 6}$ \\
\cline { 2 - 3 } & Clearly positive/favourable/good news & 7.1 \\
& More positive or favourable than negative or unfavourable & 12.9 \\
& Balanced mix between negative and positive/Neutral story, no positive & 32.5 \\
& or negative & $\mathbf{2 2 . 6}$ \\
& More negative or unfavourable than positive or favourable & $\mathbf{2 4 . 9}$ \\
\hline
\end{tabular}

From the table it is clear that reports are often fragmentized, dramatized, include an authority-disorder bias and bring negative news on the project. The personalization bias appears less often than the other information biases. About one-third of the news reports are heavily dramatized (32.7 per cent), and another third are dramatized to some

\footnotetext{
${ }^{9}$ These emboldened categories were also used to calculate the variable the number of information biases.
} 
extent (31.3 per cent). The authority-disorder bias can be found in almost half of the reports (49.6 per cent). More than three-quarters of the news reports are coded as episodic $^{10}$ (77.2 per cent). Almost half of the news reports are negative towards the water management projects (47.5 per cent). 'Only' about a quarter of the news reports are highly or moderately personalized (23.8 per cent). It might be less likely to report on these merely technical water management projects with a more personal or emotional approach than on other policy issues.

Table 4: The frequencies with regard to the number of information biases

\begin{tabular}{crrr}
\hline Number of information biases & Percentage & $\begin{array}{l}\text { Number of information biases, excl. } \\
\text { fragmentation bias }\end{array}$ & Percentage \\
\hline 0 & 4.4 & 0 & 28.1 \\
1 & 28.4 & 1 & 23.3 \\
2 & 25.3 & 2 & 23.0 \\
3 & 20.1 & 3 & 18.0 \\
4 & 17.1 & 4 & 7.6 \\
5 & 4.6 & -- & \\
\hline
\end{tabular}

Examining the number of information biases per news report, we see that 95.6 per cent include one or more information biases (see Table 4). Even excluding the fragmentization bias, we note that, in a large majority (71.9 per cent) of the news reports, one or more information biases can be found. Information biases thus definitely seem to shape the news reporting on these complex water management projects.

How do these information biases relate to the different groups of actors studied in the previous section?

\footnotetext{
${ }^{10}$ The fragmentization bias frequencies are quite different for the five cases; this may result from different interpretations of Patterson's (2000) instruction on this item, which is quite broad. We have to be careful with conclusions about the fragmentization item because it may not be as reliable and valid in this study as we would like it to be. Nevertheless, in all cases, the bias is found in more than 50 per cent of the reports.
} 


\section{The relation between different key subjects in news reports and information biases}

Firstly, we show the complete picture, comparing all four groups in Kruskal-Wallis tests. The presence of four of the five information biases in news reports varies significantly when different groups of actors are the key actor in the report. The personalization bias $(\mathrm{H}(3)=56,13, \mathrm{p}<0,001)$; the dramatization bias $(\mathrm{H}(3)=47,79, \mathrm{p}<0,001)$, the authoritydisorder bias $(\mathrm{H}(3)=19,09, \mathrm{p}<0,001)$ and the negativity bias $(\mathrm{H}(3)=49,37, \mathrm{p}<0,001)$ show significantly different mean ranks among the different groups of key subjects in the news reports. The fragmentization bias, however, did not show significant differences $(\mathrm{H}(3)=2.20, \mathrm{p}=0.532)$; we therefore did not perform pairwise comparisons concerning this bias.

In the post-hoc test provided by SPSS 20.0, the mean ranks regarding the other four biases are compared in pairs. Fig. 1 presents the results. We adjusted the figures presented by SPSS to increase the clarity and readability of the figures. The numbers represent the mean ranks of the four groups of key subjects on the information biases in the Kruskal-Wallis test. For instance, with regard to the dramatization bias, 'governing officials $246.02^{\prime}$ indicates that the average of the ranks assigned to scores within the group 'governing officials as key subject' is 246.02 .

The differences between these mean ranks are tested for significance. Solid lines between groups of key actors indicate significant differences between the groups regarding their mean rank on one of the information biases; conversely, the dashed lines indicate non-significant differences between the groups of actors. The mean rank of governing officials regarding the dramatization bias (246.02) is thus significantly different from the mean rank of unofficial actors (316.05). 

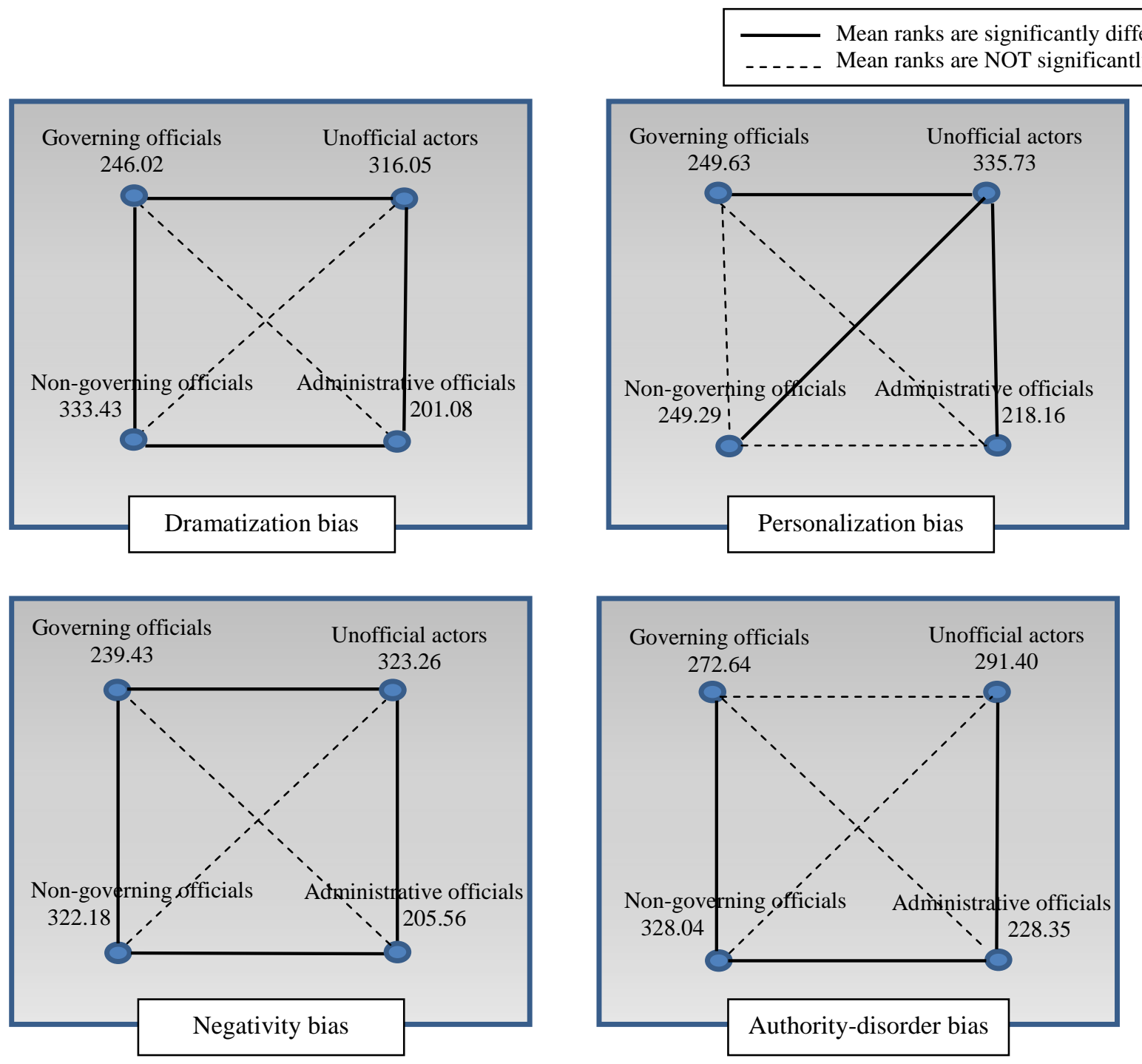

Figure 1: Graphic representation of pairwise comparisons concerning four information biases across four groups of key subjects

The governing officials and administrative officials score the lowest mean ranks on all information biases (except for the personalization bias, where the non-governing officials score a few decimals lower than the governing officials). In most of the graphics, these lower mean ranks can be contrasted with the higher mean ranks of unofficial actors 
and non-governing officials. Thus, most information biases are more present when news reports have an unofficial actor or a non-governing official as their key subject.

The solid and dashed lines clearly show this contrast between the governing and administrative officials versus the non-governing officials and unofficial actors regarding the dramatization bias and the negativity bias. Non-governing officials or unofficial actors as key subjects lead to more conflict and more negativity in the news report.

Given the line pattern of the personalization bias, we note that this bias mostly relates to the unofficial actors as key actors in the news report. The unofficial actors can in this regard clearly be contrasted with the other groups of key actors, who all score significantly lower mean ranks on the personalization bias.

The authority-disorder bias shows a more complex pattern of pairwise comparisons. The non-governing officials have the highest mean rank on this variable; this differs significantly from that of the governing officials and administrative officials, but not from that of the unofficial actors. So far, this is comparable to what we found regarding the dramatization bias and the negativity bias. However, the mean rank of the authority-disorder bias in news reports on unofficial actors is in itself comparable to the mean rank of news reports on governing officials. In summary, the different results of the Kruskal-Wallis tests confirm that the presence of four of the five information biases vary to the extent that key subjects vary. We can therefore reject these null hypotheses for $\mathrm{H} 3$. The mean ranks regarding the dramatization bias, the negativity bias, the personalization bias and the authority-disorder bias of the different groups of key actors differ significantly. However, the mean rank concerning the fragmentization bias of the 
different groups of key actors does not differ significantly; we thus retain this null hypothesis.

In the next sections, we discuss more extensively the comparative analysis of the information biases among reports in which governing officials are key actors versus reports in which unofficial actors and non-governing officials are key actors. We provide the results of the pairwise comparisons with post-hoc tests, correcting for the type I error by the Dunn-Bonferroni test, and the effect sizes, to test H4 and H5 exhaustively.

\section{Governing officials versus unofficial actors as key actors in a news report}

As revealed in the previous section, news reports with unofficial actors as key subject are more personalized $(\mathrm{p}<0.001, \mathrm{r}=0.29)$, more dramatized $(\mathrm{p}<0.001, \mathrm{r}=0.22)$ and more negative $(\mathrm{p}<0.001, \mathrm{r}=0.26)$ than news reports on governing officials. Stories about unofficial actors, mostly citizen groups, seem to have provided more conflict, more negativity and more human interest to the journalists. The reported effect sizes (r) represent all small to medium effects; they are just under the 0.3 threshold for a medium effect.

In contrast, the pairwise comparison of unofficial actors and officials as key subject in news reports was not significant with regard to the authority-disorder bias $(\mathrm{U}=$ 18,760 , n.s.). In the news reports, we found governing officials also frequently demanding (urgent) action by their own or other governmental institutions. We presume that therefore no significant difference exists in the occurrence of the authority-disorder bias in news reports where officials or unofficial actors are key subject. 
We can thus reject most null hypotheses belonging to $\mathrm{H} 4$; the personalization bias, dramatization bias and the negativity bias are significantly more often present in news on unofficial actors than in news on governing officials. However, we need to retain the null hypotheses that the presence of fragmentization bias and the authority-disorder bias is more or less similar, whether unofficial actors or governing officials are the key actors in the news reports.

\section{Governing officials versus non-governing officials as key actors in a news report}

The news reports on non-governing officials are more dramatized $(\mathrm{p}<0.001, \mathrm{r}=0.26)$ and more negative $(\mathrm{p}<0.001, \mathrm{r}=0.24)$ than news reports on governing officials. Furthermore, they more often show the authority-disorder bias $(\mathrm{p}<0.05, \mathrm{r}=0.18)$. Nongoverning officials seem to provide more conflict and more negativity to journalists. Furthermore, they seem to make more demands that authorities should take action. The effect sizes all indicate small to medium effects.

In contrast, the pairwise comparison did not show a significant difference concerning personalization bias $(\mathrm{U}=0,337$, n.s.). We did not find many news reports in which officials, governing or non-governing, personalize their message, or in which these officials are part of a human interest story.

In sum, we can reject most null hypotheses belonging to $\mathrm{H} 5$; dramatization bias, negativity bias and authority-disorder bias are significantly more often present in news on non-governing officials than in news on governing officials. However, we need to retain the null hypothesis that the fragmentization bias and the personalization bias are similarly 
present when non-governing officials and governing officials are key actors in news reports.

Combining the results on the official dominance thesis with the results on the information thesis leads to the conclusion that governing officials are newsworthy because of their authoritative position as such; to other actors, newsworthiness is added by information biases. These information biases can be a result of the framing of the message or the organization of an event on the part of unofficial actors or non-governing officials. Conversely, information biases can also be the product of a more attractive or independent framing on the part of journalists using the perspectives of unofficial actors or non-governing officials. Probably, it will often be a combination of these.

\section{THE ROLE OF INFORMATION BIASES IN THE FIGHT FOR MEDIA}

\section{ATTENTION}

Media attention is an important source of power within governance networks, especially in times of mediatization. Actors thus fight to attract media attention. Hence, we have studied how much media attention different groups of actors attract in complex policy processes and how media biases relate to this media attention. We have analysed official dominance and information biases in news reports on five water management projects in the Netherlands.

We observed that official actors do receive somewhat more media attention than unofficial actors in the news reports; and governing officials more than non-governing officials. Authoritativeness thus indeed seems to be an important news value; this is in line with earlier research on this topic (Bennett, 1996; Shoemaker and Reese, 1996; 
Shehata, 2010; Hopmann et al., 2011). Governing officials might at the same time benefit from the information subsidies provided by their communication professionals. However, the contrast between official and unofficial actors is not as strong as we expected following the literature on official dominance (Gans, 1979; Sigal, 1973; Tresch, 2009). From the comparison of relevant smaller subgroups, it even appeared that unofficial actors are more frequently subject of a news story than governing officials. This result might be partly explicable by the governance networks in which actors are organized, where political hierarchy is less important. In these networks, inclusion of unofficial actors is an important principle. Still, governing officials often function as the public face of decisions or policies (Eshuis and Klijn, 2012).

Another explanation is that unofficial actors benefit from information biases in news reports, which were clearly present. Many reports were fragmentized, dramatized, negative towards the project and demanded action by a governmental authority (authority-disorder bias); some were personalized. As discussed in the theoretical section, these information biases in the news can be judged differently. In line with Patterson (2000), Bennett (2009) and many others, we could argue that the complex policy process within the five water management cases are simplified and enlivened by information biases. Although news consumers are to some extent entertained by reading or viewing the news reports, we can at the same time question the extent to which they get really informed on the actual policy process. In contrast, we can also argue that the information biases are a sign of journalistic independence and even of democratization of the media debate, as Schudson (2009) and Shehata (2010) suggest. 
Media attention for unofficial actors and non-governing officials, with generally fewer power resources in governance networks, shows significantly more information biases than news on governing officials. Information biases thus seem to make it easier for these non-authoritative groups to attract media attention to their side. We do not wish to make a definitive moral judgement on information biases, but these empirical results show that information biases function as a form of checks and balances. At least they provide checks and balances in media debates; but because media attention is a power resource in decision-making processes (Cobb and Elder, 1983; Baumgartner and Jones, 2009; Sireau and Davis, 2007; Voltmer and Koch-Baumgarten, 2010; Kunelius and Reunanen, 2011), information biases might similarly affect the policy process.

In our water management cases, publicity indeed seems to have helped citizens to influence the decision-making process (van Buuren et al., 2010; A and B, 2012). In IJsseldelta-Zuid, for instance, a citizen group received much media attention for their protests against the building of new dwellings near their village. Consequently, the municipal council changed their decision in favour of the citizen group. The group clearly incorporated media logic in their strategies, organizing protests and dramatizing and personalizing their communication (A and B, 2012). Although agenda setting theory is often studied and applied in public administration, the role of media biases is often neglected in this literature on policy dynamics. It would be interesting to see more research on the role of information biases.

With regard to information biases, we found in this study that these partly differ in the patterns of relationships with the actors. News reports are frequently fragmented, and this bias does not vary across the different groups of key subjects, as the other biases 
do. The dramatization bias and negativity bias significantly relate to the media attention on unofficial actors and non-governing officials. Conflicts and negativity seem to make these actors - who lack the habitual access to the media enjoyed by officials - more newsworthy. Moreover, by organizing protests, contra-expertise and press releases (A and B, 2012), citizen groups provide journalists with information subsidies, which feed these two biases. Unofficial actors gain news value as well by incorporating the human angle in their story.

Furthermore, claiming that there is need for authorities to act increases the attractiveness of their standpoint. However, it is not only non-governing officials that use this in their communication, governing officials also do this to some extent. This is actually the only bias for which the governors do not score significantly lower than unofficial actors. Possibly governing officials to some extent become influenced by the media debate, which is full of drama and negativity, and consequently also feel the need to plead for policy plans to be amended by their own departments or other governmental authorities.

Our mainly optimistic conclusion should be tempered by the fact that we did not study exact qualitative content in this research. It should be borne in mind that, when an actor is coded as key subject of a news report, this does not necessarily mean that his/her perspective is correctly described in the story. According to the more pessimistic accounts of Bennett (2009) and Patterson (2000), his/her vision will often be simplified. Moreover, following this line of reasoning, we cannot and do not claim, on the basis of our results, that viewpoints of groups of actors are equally represented in the media debate. Probably, it is mainly unofficial and non-governing actors that are covered in 
news reports because of their greater newsworthiness in terms of drama and conflict, and thus obviously information biases are more likely to feature.

Nevertheless, we do not want to downplay the positive side of these information biases. The debate on policy plans can be enriched by issues raised by unofficial actors or non-governing officials in news reports and this can be partly attributed to information biases in news reporting. 


\section{References}

Altheide, D. L. and Snow, R. P. (1979) Media Logic. Beverly Hills: Sage.

Baumgartner, F. R. and Jones, B. D. (2009) Agendas and Instability in American Politics. Chicago: University of Chicago Press.

Bennett, W. L. (1996) An Introduction to Journalism Norms and Representation of Politics. Political Communication, 13:4 pp373-84.

Bennett, W.L. (2009) News. The Politics of Illusion. New York: Pearson Longman.

Brants, K. and Neijens, P. (1998) The Infotainment of Politics. Political Communication, 15:2 pp149-64.

Brants, K. and van Praag, P. (2006) Signs of Media Logic. Half a Century of Political Communication in the Netherlands. Javnost - The Public, 13:1 pp25-40.

Cobb, R. W. and Elder, C. D. (1983) Participation in American Politics. The Dynamics of Agenda-Building. Baltimore: The Johns Hopkins University Press.

Conover, W.J. and Iman, R.L. (1981). Rank Transformations as a Bridge Between Parametric and Nonparametric Statistics. The American Statistician, 35:3 pp 124129

Cook, T. (2005) Governing with the News. Chicago: University of Chicago Press.

Davis, A. (2007) The Mediation of Power: A Critical Introduction. London: Routledge.

Delli Carpini, M. X. and Williams, B. A. (2001) 'Let Us Infotain You: Politics in the New Media Age,' in: L. W. Bennett and R. M. Entman (eds.) Mediated Politics. Communication in the Future of Democracy. Cambridge: Cambridge University Press. 
Entman, R. M. (2007) Framing Bias: Media in the Distribution of Power. Journal of Communication, 27:57 pp163-73.

Eshuis, J. and Klijn, E.-H. (2012) Branding in Governance and Public Management. New York: Routledge.

Field, A. (2009). Discovering Statistics using SPSS. London: Sage Publications

Gandy, O. H. (1982) Beyond Agenda Setting: Information Subsidies and Public Policy. Norwood, NJ: Ablex.

Gans, H. J. (1979) Deciding What's News: A Study of CBS Evening News, NBC Nightly News, Newsweek and Time. New York: Pantheon Books.

Hajer, M. A. (2009) Authoritative Governance. Policy-Making in the Age of Mediatization. Oxford: Oxford University Press.

Hisschemöller, M. and Hoppe, R. (1995) Coping with Intractable Controversies: The Case for Problem Structuring in Policy Design and Analysis. Knowledge and Policy: The International Journal of Knowledge Transfer and Utilization, 8:4 pp40-60.

Hjarvard, S. (2008) The Mediatization of Society: A Theory of the Media as Agents of Social and Cultural Change. Nordicom Review, 29: 2 pp105-34.

Hopmann, D. N., de Vreese, C. H. and Albæk, E. (2011) Incumbency Bonus in Election News Coverage Explained: The Logics of Political Power and the Media Market. Journal of Communication, 61:2 pp264-82.

Hurrelmann, A., Krell-Laluhovà, Z., Nullmeier, F., Schneider, S. and Wiesner, A. (2009) Why the Democratic Nation-State Is Still Legitimate: A Study of Media Discourses. European Journal of Political Research, 48:4 pp483-515. 
Iyengar, S. and McGrady, J. A. (2007) Media Politics. A Citizen's Guide. New York: W.W. Norton \& Company.

Kleinnijenhuis, J., van Hoof, A. M. J. and Oegema, D. (2006) Negative News and the Sleeper Effect of Distrust. Harvard International Journal of Press and Politics, 11:2 pp86-104.

Klijn, E.-H. (2008) Governance and Governance Networks in Europe. An Assessment of Ten Years of Research on the Theme. Public Management Review, 10:4 pp50525.

Koppenjan, J. F. M and Klijn, E.-H. (2004) Managing Uncertainties in Networks. A Network Approach to Problem Solving and Decision Making. New York: Routledge.

Koppenjan, J. F. M. (2007) 'Consensus and Conflict in Policy Networks: Too Much or Too Little?' in E. Sorensen and J. Torfing (eds) Theories of Democratic Network Governance. New York: Palgrave.

Krippendorf, K. (2004) Content Analysis. Thousand Oaks: Sage.

Kunelius, R. and Reunanen, E. (2012) Media in Political Power: A Parsonian View on Differentiated Mediatization of Finnish Decision Makers. The International Journal of Press/Politics, 17:1 pp 56-75.

Lieber, P. S. and Golan, G. J. (2011) 'Political Public Relations, News Management, and Agenda Indexing' in J. Ströbäck and S. Kiousis (eds) Political Public Relations. Principles and Applications. New York: Routledge.

Mason, R. O. and Mitroff, I. I. (1981) Challenging Strategic Planning Assumptions. Theory, Cases and Techniques. New York: John Wiley \& Sons, Inc. 
Mazzoleni, G., and Schulz, W. (1999) 'Mediatization' of Politics: A Challenge for Democracy? Political Communication, 16:3 pp247-61.

Parkinson, J. (2006) Notes and Comment. Rickety Bridges: Using the Media in Deliberative Democracy. British Journal of Political Science, 36:1 pp175-83.

Patterson, T. E. (2000) Doing Well and Doing Good: How Soft News and Critical Journalism Are Shrinking the News Audience and Weakening Democracy - and What News Outlets Can Do About It. Boston, MA: Joan Shorenstein Center on the Press, Politics and Public Policy, Kennedy School of Government, Harvard University.

Reunanen, E., Kunelius, R. and Noppari, E. (2010) Mediatization in Context: Consensus Culture, Media and Decision Making in the 21st Century, The Case of Finland. Communications, 35:3 pp287-307.

Rittel, W. J. and Webber, M. (1973) Dilemmas in a General Theory of Planning. Policy Sciences, 4:2 pp155-69.

Schudson, M. (2009) Why Democracies Need an Unlovable Press. Cambridge: Polity Press.

Semetko, H. A. and Valkenburg, P. M. (2000) Framing European Politics: A Content Analysis of Press and Television News. Journal of Communication, 50:2 pp93109.

Shehata, A. (2010) Marking Journalistic Independence: Official Dominance and the Rule of Product Substitution in Swedish Press Coverage. European Journal of Communication, 25:2 pp123-37. 
Shoemaker, P. J. and Reese, S. D. (1996) Mediating the Message. Theories of Influences on Mass Media Content. New York: Longman.

Sigal, L. V. (1973) Reporters and Officials: The Organization and Politics of Newsmaking. Lexington, MA: D.C. Heath and Company.

Sireau, N. and Davis. A. (2007) 'Interest Groups and Mediated Mobilization. Communication in the Make Poverty History Campaign' in A. Davis (ed.) The Mediation of Power: A Critical Introduction. London: Routledge.

Sorensen, E. and Torfing, J. (2005) Network Governance and Post-Liberal Democracy. Administrative Theory and Praxis, 27:2 pp197-237.

Spörer-Wagner, D. and Marcinkowski, F. (2010) Is Talk Always Silver and Silence Golden? The Mediatisation of Political Bargaining. Javnost - The Public, 17:2 pp5-26.

Strömbäck, J. and Shehata, A. (2007) Structural Biases in British and Swedish Election News Coverage. Journalism Studies, 8:5 pp798-815.

Strömbäck, J. and Esser, F. (2009) 'Shaping Politics: Mediatization and Media Interventionism' in K. Lundby (ed.) Mediatization. Concept, Changes, Consequences. New York: Peter Lang.

Terkildsen, N., Schnell, F. I., and Ling, C. (1998). Interest Groups, the Media, and Policy Debate Formation: An Analysis of Message Structure, Rhetoric and Source Cues. Political Communication, 15:1 pp45-61.

Tresch, A. (2009) Politicians in the Media: Determinants of Legislators' Presence and Prominence in Swiss Newspapers. The International Journal of Press/Politics, 14:1 pp67-90. 
van Buuren, A. W., Edelenbos J. and Klijn, E.-H. (2010) Gebiedsontwikkeling in woelig water. Over water governance bewegend tussen adaptief waterbeheer en ruimtelijke besluitvorming [Area Development in Turbulent Water. About Water Governance Moving between Adaptive Water Management and Spatial Planning]. Den Haag: Lemma.

Voltmer, K. and Koch-Baumgarten, S. (2010) 'Introduction. Mass Media and Public Policy - Is There a Link?' in S. Koch-Baumgarten and K. Voltmer (eds) Public Policy and Mass Media. The Interplay of Mass Communication and Political Decision Making. New York: Routledge.

Wester, F. and van Selm, M. (2006). 'Inhoudsanalyse als systematisch-kwantificerende werkwijze' ['Content Analysis as Systematic-Quantifying Method'] in F. Wester, K. Renckstorf, and P. Scheepers (Eds) Onderzoekstypen in de communicatiewetenschap [Types of Research within Communication Studies]. Alphen aan de Rijn: Kluwer. 
Appendix 1 Conceptualization of the variables

(This conceptualization can be found in Patterson, 2000: 24-6)

\begin{tabular}{|c|c|c|}
\hline Variable & Definition & Categories \\
\hline Personalization bias & $\begin{array}{l}\text { The use of the human interest frame. Human interest } \\
\text { stories use a human example or put a 'human face' on } \\
\text { an issue or problem, or go into the private or personal } \\
\text { life of an actor and/or journalist, employing adjectives } \\
\text { or personal vignettes that generate feelings of } \\
\text { sympathy, empathy or outrage. }\end{array}$ & $\begin{array}{l}\text {-High human interest content } \\
\text {-Moderate human interest content } \\
\text {-Slight human interest content } \\
\text {-No (or merely incidental) human } \\
\text { interest content }\end{array}$ \\
\hline Dramatization bias & $\begin{array}{l}\text { Based on story, and the way story is presented, not on } \\
\text { the topic of the story. }\end{array}$ & $\begin{array}{l}\text {-Substantial level of conflict } \\
\text {-Some conflict (not merely incidental) } \\
\text {-No conflict (or so slight as to be } \\
\text { inconsequential) }\end{array}$ \\
\hline $\begin{array}{l}\text { Fragmentization } \\
\text { bias }\end{array}$ & $\begin{array}{l}\text { Episodic (story, not topic) mainly in the context of a } \\
\text { particular event, incident; the story does not go much } \\
\text { beyond that specific event; the story takes the form of } \\
\text { a case-study). Thematic (story itself, not topic) mainly } \\
\text { in a broader context that deals with its meaning or } \\
\text { implications for society, a trend that goes beyond this } \\
\text { single event/incident; story places public issues in a } \\
\text { broad or abstract context }\end{array}$ & $\begin{array}{l}\text {-Episodic story } \\
\text {-Thematic story }\end{array}$ \\
\hline \multirow[t]{2}{*}{$\begin{array}{l}\text { Authority-disorder } \\
\text { bias }\end{array}$} & $\begin{array}{l}\text { When the story implies a need for action or suggests } \\
\text { action should be taken, the action frame is present. } \\
\text { We combined this item with another code: the } \\
\text { attribution of responsibility. When the story implies a } \\
\text { need for action and the government is given the } \\
\text { responsibility for that, the authority-disorder bias is } \\
\text { present. }\end{array}$ & $\begin{array}{l}\text { Action/non action frame } \\
\text {-Story implies/says there is an urgent need for } \\
\text { action/describes a problem (and by direct statement } \\
\text { or implication indicates the problem needs to be } \\
\text { fixed); suggests action should be taken, would be } \\
\text { desirable, etc. (can be public or personal action). } \\
\text {-Story implies/says there is a non-urgent need for } \\
\text { action/describes a problem (and by direct statement } \\
\text { or implication indicates the problem needs to be } \\
\text { fixed); suggests action should be taken, would be } \\
\text { desirable, etc. (can be public or personal action). } \\
\text {-Story describes action already taken or being taken } \\
\text { to resolve the problem } \\
\text {-No action component of note }\end{array}$ \\
\hline & & $\begin{array}{l}\text { Attribution responsibility } \\
\text {-Not applicable - coded } 4 \text { in previous code } \\
\text {-Government/some level of government/a } \\
\text { governmental institution or an individual public } \\
\text { official (e.g. the president, mayor ) } \\
\text {-A group, or collective, or community in society or } \\
\text { a private institution } \\
\text {-Private individual }\end{array}$ \\
\hline Negativity & $\begin{array}{l}\text { This code is designed to pick up whether the story is } \\
\text { thought on the whole to be in the good news or bad } \\
\text { news category. In some instances, it might be helpful } \\
\text { to ask the following questions: If about a newsmaker } \\
\text { and you were his/her press secretary, would you } \\
\text { consider this a favourable or an unfavourable story? If } \\
\text { about an institution (e.g. Congress), does this reflect } \\
\text { favourably or unfavourably on the institution? If about } \\
\text { a development (e.g. a social trend, event or incident) } \\
\text { is this a good or bad thing for society?) } \\
\text { For this research, we coded whether the report was } \\
\text { favourable or unfavourable towards the water } \\
\text { management project. }\end{array}$ & $\begin{array}{l}\text {-Clearly negative/unfavourable/bad news } \\
\text {-More negative or unfavourable than positive or } \\
\text { favourable } \\
\text {-Balanced mix between negative and positive } \\
\text {-More positive or favourable than negative or } \\
\text { unfavourable } \\
\text {-Clearly positive/favourable/good news } \\
\text {-Neutral story, no positive or negative }\end{array}$ \\
\hline $\begin{array}{l}\text { Most important } \\
\text { actor in the report }\end{array}$ & & $\begin{array}{l}\text { Prime minister } \\
\text { Minister } \\
\text { Member of the lower house } \\
\text { National government official } \\
\text { The state } \\
\text { Provincial governor } \\
\text { Delegate from the provincial executive/councillor } \\
\text { The province } \\
\text { Metropolitan region } \\
\text { Water authority } \\
\text { Mayor } \\
\text { Aldermen }\end{array}$ \\
\hline
\end{tabular}


Municipal councillor

The municipality

Inhabitants

Farmers

Environmental organizations

Project organization

Private investor

Research institute

Other 